\section{Sham CPAP}

Helga Peter

Marburg, Deutschland

\section{Definition}

Schein-CPAP, von engl. sham, unecht. Es wird gegeben, um in kontrollierten klinischen Studien die Wirksamkeit von > „CPAP“ zu überprüfen.

Siehe auch $\triangleright$ „Kardiovaskuläre Effekte der nasalen Ventilationstherapie bei Schlafbezogenen Atmungsstörungen“. 